Article

\title{
Comprehensive Transcriptome Analysis Reveals Insights into Phylogeny and Positively Selected Genes of Sillago Species
}

\author{
Fangrui Lou ${ }^{1}$, Yuan Zhang ${ }^{2}$, Na Song ${ }^{2}$, Dongping Ji ${ }^{3}$ and Tianxiang Gao ${ }^{1, *}$ \\ 1 Fishery College, Zhejiang Ocean University, Zhoushan 316022, Zhejiang, China; lfr199202@163.com \\ 2 Fishery College, Ocean University of China, Qingdao 266003, Shandong, China; \\ zhangyuan_ouc@163.com (Y.Z.); songna624@163.com (N.S.) \\ 3 Agricultural Machinery Service Center, Fangchenggang 538000, Guangxi, China; jidongping201@163.com \\ * Correspondence: gaotianxiang0611@163.com; Tel.: +86-580-2089-333
}

Received: 24 February 2020; Accepted: 1 April 2020; Published: 7 April 2020

Simple Summary: A comprehensive transcriptome analysis revealed the phylogeny of seven Sillago species. Selection force analysis in seven Sillago species detected 44 genes positively selected relative to other Perciform fishes. The results of the present study can be used as a reference for the further adaptive evolution study of Sillago species.

\begin{abstract}
Sillago species lives in the demersal environments and face multiple stressors, such as localized oxygen depletion, sulfide accumulation, and high turbidity. In this study, we performed transcriptome analyses of seven Sillago species to provide insights into the phylogeny and positively selected genes of this species. After de novo assembly, 82,024, 58,102, 63,807, 85,990, 102,185, 69,748, and 102,903 unigenes were generated from S. japonica, S. aeolus, S. sp.1, S. sihama, S. sp.2, S. parvisquamis, and S. sinica, respectively. Furthermore, 140 shared orthologous exon markers were identified and then applied to reconstruct the phylogenetic relationships of the seven Sillago species. The reconstructed phylogenetic structure was significantly congruent with the prevailing morphological and molecular biological view of Sillago species relationships. In addition, a total of 44 genes were identified to be positively selected, and these genes were potential participants in the stress response, material (carbohydrate, amino acid and lipid) and energy metabolism, growth and differentiation, embryogenesis, visual sense, and other biological processes. We suspected that these genes possibly allowed Sillago species to increase their ecological adaptation to multiple environmental stressors.
\end{abstract}

Keywords: Sillaginidae; bottom dweller; RNA-seq; orthologous exon markers; positive selection

\section{Introduction}

The fish family Sillago are commonly known as sand whitings or sand borers, which are widely distributed in inshore waters of the Indian Ocean and the western Pacific Ocean and thrive in estuaries and shoals [1]. As minitype bottom-dwelling fishes of shallow sea regions, Sillago species are gregarious and have the ecological habit of drilling sand [2]. In addition, the Sillago species have become an important economical edible fish due to their palatable meat and long chain fatty acids that prevent thrombosis [2]. The inshore fishing of Sillago species has also developed rapidly in the past decades. It is worth noting that the overfishing will eventually lead to the ecological and economic damage of the Sillago resource. Additionally, more complex demersal environments caused by climate change and human activities, such as localized oxygen depletion, sulfide accumulation, and high turbidity, also 
pose a challenge to Sillago species differentiation and survival [3]. Therefore, it is necessary to develop the management and restoration of Sillago fishery resources.

Inferring the phylogenetic relationships is fundamental to successfully managing and recovering Sillago fishery resources, allowing the identification of the origin and relationship of species and the revelation of the evolutionary processes that lead to species diversity. At present, eleven Sillago species have been recorded in China [4]. Although there exist few taxa in Sillago, species identification and phylogenetic status are often confusing to taxonomists due to their similar phenotypic and physiological characteristics [2]. Additionally, local environmental divergences and rapid climatic changes could lead to the further diversification and speciation of Sillago, ultimately improving the complexity of phylogenetic research of Sillago species [5]. Although significant development has been reported in recent years, the knowledge of the phylogeny of Sillago species is still controversial, especially in the process of identifying cryptic lineages within the vast diversity of Sillago through the analysis of different phenotypic characteristics. Particular points of contention include (i) the incorrect use of species' scientific names and (ii) species identification errors from identification based only on morphological features [1,2,4]. The application of comprehensive molecular phylogenies upended classical morphological hypotheses and led to the development of a new Sillago phylogenetic classification method. For example, four Sillago species, including Sillago caudicula [2], S. sinica [6], S. suezensis [7], and S. shaoi [4] were reclassified using molecular markers, although they were all wrongly classified as $S$. sihama based on phenotypic traits. It is impossible to construct a comprehensive phylogenetic relationship for Sillago species only by using a single or small number of gene fragments. This is the case because a small number of gene fragments contain limited genetic information, and therefore cannot provide high statistical support for some crucial branches of the phylogenetic tree [8]. Different gene fragments are also affected by sequence conservation, gene evolution rate differences, horizontal gene transfer, and other factors, which ultimately lead to conflicting gene trees [9]. Additionally, it is undeniable that all previous studies only analyzed the differentiation between Sillago species, while the genetically adaptive characteristics were still not clear. Therefore, it is very essential to investigate the molecular features of different Sillago species based on complete genetic information, which will provide us with an accurate understanding of differentiation and environmental adaptation in Sillago species.

The sequence differentiation of orthologous genes is related to speciation, and therefore, orthologous genes can be used to infer more accurate phylogenetic relationships among species [10]. Currently, the advent and increasingly widespread use of high-throughput sequencing technologies provides hundreds to thousands of orthologous genes for the phylogenetic analysis of species [11,12]. However, it is worth noting that the massive datasets generated by high-throughput sequencing, especially whole genome datasets, require more complex analytical methods to confirm the most informative orthologous loci and appropriate tree reasoning methods [13]. For vertebrates (including teleost), two whole-genome duplications (WGDs) eventually produced duplicate genes, which further affected the accuracy of distinguishing orthologous genes from duplicated paralogs [14,15]. In Sillago species, unfortunately, there is only the $S$. sinica genome project that has been sequenced [5]. Modern transcriptome datasets may avoid the defects mentioned above, because they can effortlessly generate massive genome-wide protein-coding sequences for phylogenetic studies, especially when whole genomic information is not available [10]. Meanwhile, we can focus on calculating and comparing the gene evolutionary rates based on orthologous gene datasets, and then infer the potential local environmental adaptation genes of organisms $[16,17]$. In brief, we believe that the phylogenetic relationships and genetic adaptation characteristics will be successively identified in Sillago species by orthologous gene analysis. 
In order to reconstruct the complete phylogenetic relationship of Sillago species and detect their genomic characters associated with adaptive evolution, five valid Sillago species (including S. japonica, S. aeolus, S. sihama, S. parvisquamis, and S. sinica) and two unpublished new species (S. sp.1 and S. sp.2; unpublished data)—which were confirmed by using morphological, anatomical, and DNA-barcoding evidence-were studied. Next, seven RNA sequencing (RNA-seq) libraries were constructed together. First, clean reads produced by RNA-seq were applied to assemble seven relatively integrated transcriptomes of Sillago species. Subsequently, transcriptome data of seven Sillago species and other existing Perciformes species were detected for orthologous genes, and then the shared orthologous genes were used to reconstruct the phylogenetic tree and predict the differentiation time. Considering that these genes that experience positive selection may be beneficial to improving the ecological adaptation of Sillago species, we investigated the positively selected genes (PSGs) of Sillago species based on orthologous genes. Meanwhile, a gene function enrichment analysis was performed on these PSGs. These results can constitute important data with which to gain insights into the process of species differentiation and adaptive evolution in other Sillago species.

\section{Materials and Methods}

\subsection{Ethics Approval and Consent to Participate}

The Sillago species are not endangered or protected species in China or other countries. In addition, frost anesthesia was used to minimize suffering in all samples.

\subsection{Sample Collection, RNA Extraction, and Illumina Sequencing}

Seven Sillago species were obtained from the coast of China and Japan. Then, one adult female per species was immediately euthanized, and the muscle of each individual was rapidly sampled, snap-frozen in liquid nitrogen, and stored at $-80{ }^{\circ} \mathrm{C}$ prior to the RNA extraction. The sampling location and the standard length (SL) of each sequenced individual are shown in Figure 1. The total RNA of the seven Sillago species was extracted using a standard TRIzol Reagent kit, following the manufacturer's protocol. The quantitative evaluation of total RNA was conducted by using the Agilent 2100 Bioanalyzer (Agilent Technologies, Santa Clara, CA, USA). We then purified mRNA by depleting rRNA from total RNA, and the remaining mRNA was cleaned three times. Then, we fragmented the mRNA into fragments of appropriate size. The fragmented mRNA was used to construct a cDNA library. Afterwards, we added A-tails and adapters to the double stranded cDNA. Then, the cDNA libraries were diluted to $10 \mathrm{pM}$ and then quantified by using the Agilent 2100 Bioanalyzer. Finally, each tagged cDNA library was sequenced on the Illumina HiSeq 2000 across one lane with paired-end 150 bp reads. 


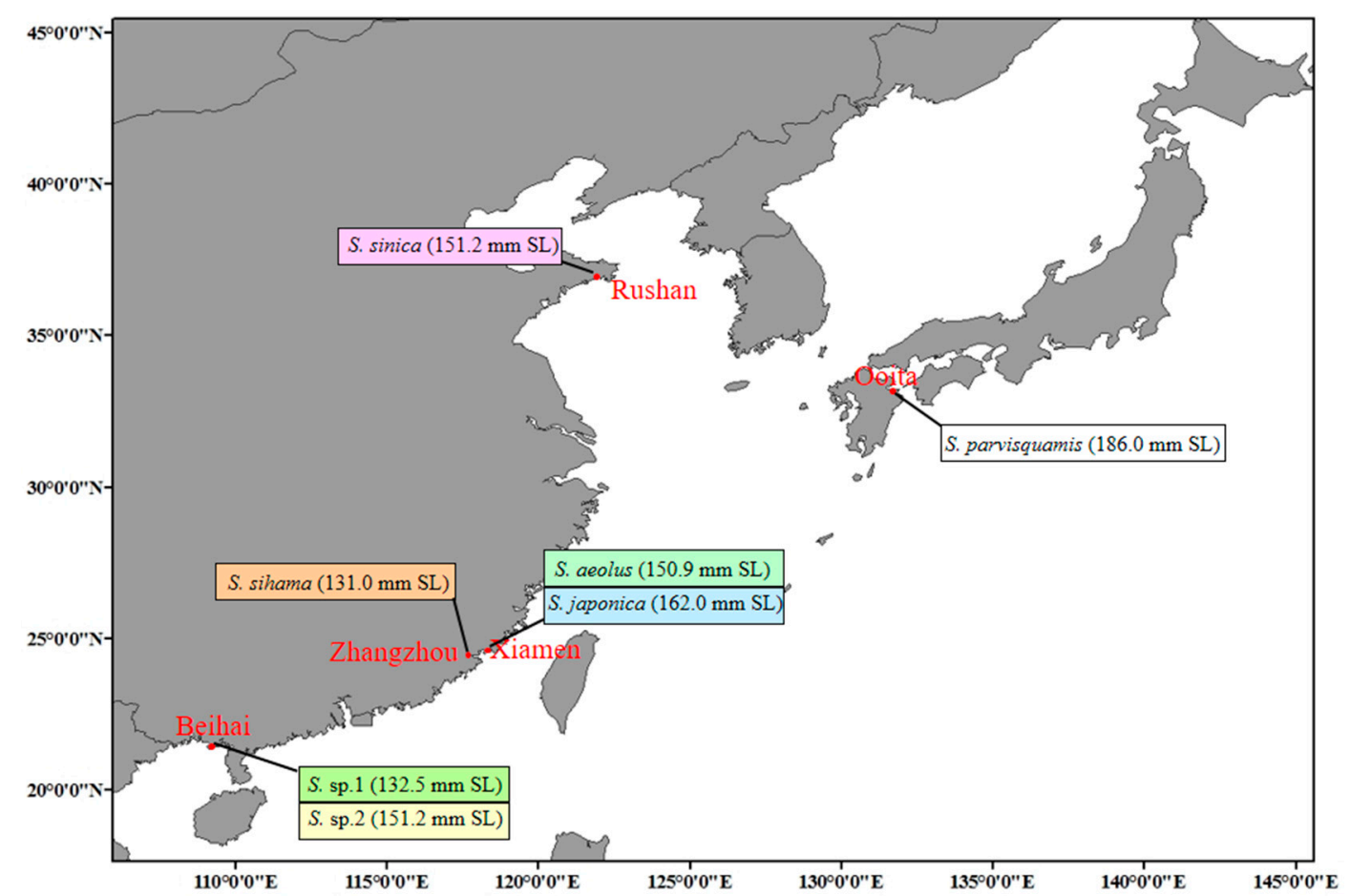

Figure 1. The sampling location and standard length (SL) of each sequencing individual.

\subsection{Transcriptome De Novo Assembly}

The raw RNA-seq data of Sillago japonica, Sillago aeolus, Sillago sihama, Sillago parvisquamis, Sillago sinica, Sillago sp.1 and Sillago sp.2 reported in this paper have been deposited in the Sequence Read Archive (SRA) database of National Center for Biotechnology Information (NCBI) under BioProject number PRJNA596307, with accession number of SRR10743284, SRR10743285, SRR10743281, SRR10743280, SRR10743279, SRR10743282 and SRR10743283, respectively. The FastQC 0.11.2 software (version, Babraham Institute, Cambridgeshire, UK) was applied to assess the sequencing quality of all raw reads in FASTQ format. Then, clean reads were obtained by removing reads with sequencing adapters, unknown nucleotides ( $\mathrm{N}$ ratio $>10 \%$ ), and low quality (quality scores $<20$ ) using Trimmomatic 0.36 [18]. Additionally, the S. sinica genome dataset served as a reference sequence and was used for subsequent de novo assembly [5]. All remaining high-quality clean reads were sorted according to $S$. sinica genome index sequences and were aligned to the reference assembly generated from paired-end reads by using the bwa-mem algorithm in the BWA (Version 0.7.12, Microsoft Corporation, Redmond, WA, USA; [19]) software with default parameters, with the resulting output as 'sam' files. All sam files of each species were merged into a 'bam' file using the SAMtools (Version 1.3.1; Microsoft Corporation, Redmond, WA, USA; [20]) software. Finally, the Trinity (Version 2.4.0, Microsoft Corporation, Redmond, WA, USA; [21]) software was used for the transcriptome de novo assembly of each species, with the parameters as follows: -genome_guided_max_intron 10000. In order to perform further quantitative assessment of the assembly completeness, we applied the BUSCO software (version 4.0, Microsoft Corporation, Redmond, WA, USA) package with default settings, and downloaded the Ensembl Actinopterygii assembly as a reference. 


\subsection{Orthology Determination and Phylogenetic Tree Reconstruction}

In order to reconstruct a more accurate phylogenetic tree, we performed an extensive orthologous gene comparison among the seven Sillago species and thirteen other Perciformes species (hereafter referred to as the "research species") with transcriptome or genome datasets, including Epinephelus fuscoguttatus (GCNQ00000000.1), Epinephelus coioides (GCA_900536245.1), Perca fluviatilis (GCA_003412525.1), Chionodraco hamatus (GCA_009756495.1), Gymnodraco acuticeps (GGFR00000000.1), Dissostichus eleginoides (GHKE00000000.1), Trematomus bernacchii (GBXS00000000.1), Argyrosomus regius (GFVG00000000.1), Nibea albiflora (GCA_900327885.1), Miichthys miiuy (GCA_001593715.1), Collichthys lucidus (GCA_004119915.1), Larimichthys polyactis (GETG00000000.1), and Larimichthys crocea (GCA_000972845.2). Meanwhile, the ecological characteristics of the 20 research species were obtained from the Fishbase website [22] and the research results of Xiao et al. (2016) [4], as shown in Table 1. Firstly, we obtained the assembly sequences from the National Center for Biotechnology Information (NCBI) database under the accession number. Additionally, a dataset of 1721 single-copy conserved nuclear coding sequences (> 200bp) was obtained by comparing and optimizing eight well-annotated model fish genomes: Lepisosteus oculatus, Anguilla anguilla, Danio rerio, Gadus morhua, Oryzias latipes, Oreochromis niloticus, Gasterosteus aculeatus, and Tetraodon nigroviridis [23]. Subsequently, we extracted the single-copy conserved nuclear coding sequences of each research species using the HMMER software (Version 3.1, Howard Hughes Medical Institute, Chevy Chase, MD, USA; [24]). Specifically, 1721 parameterized hidden Markov model (HMM) profiles were obtained based on 1721 sequence alignments using the 'hmmbuild' function of the HMMER software. Each HMM model was applied to search against each research species dataset using the nHMMER program within HMMER, with the resulting hits output as a table. We used Python scripts (available on Dryad; [23]) to retain the hits that were at least $70 \%$ as long as the shortest model fragment and had a bit score of at least 100, and de-redundancy was performed on these hits with 100\% similarity by using the CD-HIT software [25]. The remaining high-quality single-copy conserved nuclear coding sequences of each research species were aligned and spliced into single nucleotide sequences using the MAFFT software [26]. Conserved sequences were extracted from each concatenated nucleotide sequence using Gblocks with parameter $-t=c$ [27]. Finally, we performed 1000 nonparametric bootstrap replicates for the optimal GTRGAMMA substitution model of all concatenated nucleotide sequences in the MEGA (Version 6.0, National Institutes of Health, Bethesda, MD, USA; [28]) software, and then a complete neighbor-joining (NJ) tree of the abovementioned twenty species was reconstructed according to the branch lengths and bootstrap support values. Additionally, we also reconstructed the NJ trees based on the amino acid sequences and variation sites of concatenated nucleotide sequences. The iTol (Version 4.0, Beijing Institute of Genomics, Beijing, China; [29]) software was used to visualize the phylogenetic relationship. Finally, the estimated molecular clock data of L. polyactis and L. crocea (min and max differentiation times are 11.2 and 42.0 MYA) were obtained from the TimeTree database [30], and then the divergence times of the seven Sillago species were estimated using the r8s software [31]. 
Table 1. The ecological characteristics of 20 research species.

\begin{tabular}{|c|c|c|c|c|c|c|c|}
\hline Species & Classification & Milieu & $\begin{array}{l}\text { Climate } \\
\text { Zone }\end{array}$ & $\begin{array}{c}\text { Depth } \\
\text { Range (M) }\end{array}$ & $\begin{array}{c}\text { Maturity } \\
\text { Length }(\mathrm{cm})\end{array}$ & $\begin{array}{c}\text { Feeding } \\
\text { Habits }\end{array}$ & $\begin{array}{l}\text { Type of Fish } \\
\text { Eggs }\end{array}$ \\
\hline E. fuscoguttatus & Serranidae & Marine; brackish; reef-associated & Tropical & $1-60$ & 50 & Carnivorous & Pelagic \\
\hline E. coioides & Serranidae & Marine; brackish; reef-associated & Subtropical & $1-100$ & $25-30$ & Carnivorous & Pelagic \\
\hline P. fluviatilis & Percidae & Freshwater; brackish; demersal & Temperate & $1-30$ & $11-23.4$ & Carnivorous & Adhesive \\
\hline C. hamatus & Channichthyidae & Marine; demersal & Polar & $4-600$ & $33-37$ & Carnivorous & Pelagic \\
\hline G. acuticeps & Bathydraconidae & Marine; demersal & Polar & $0-550$ & - & Carnivorous & Pelagic \\
\hline D. eleginoides & Nototheniidae & Marine; demersal & Temperate & $50-3850$ & $38-60$ & Carnivorous & Pelagic \\
\hline T. bernacchii & Nototheniidae & Marine; demersal; & Polar & $0-700$ & 18 & Carnivorous & Pelagic \\
\hline A. regius & Sciaenidae & Marine; brackish; demersal & Subtropical & $15-300$ & 80 & Carnivorous & Pelagic \\
\hline N. albiflora & Sciaenidae & $\begin{array}{l}\text { Marine; demersal; coastal waters with mudddy to } \\
\text { sanddy-muddy bottoms }\end{array}$ & Temperate & $25-80$ & - & Carnivorous & Pelagic \\
\hline M. miiuy & Sciaenidae & $\begin{array}{l}\text { Marine; brackish; demersal; coastal waters with } \\
\text { mudddy to sanddy-muddy bottoms }\end{array}$ & Temperate & $15-100$ & - & Carnivorous & Pelagic \\
\hline C. lucidus & Sciaenidae & $\begin{array}{l}\text { Marine; demersal; coastal waters with mudddy to } \\
\text { sanddy-muddy bottoms }\end{array}$ & Subtropical & 0-90 & 13 & Carnivorous & Pelagic \\
\hline L. polyactis & Sciaenidae & $\begin{array}{l}\text { Marine; demersal; sublittoral zone above } 120 \mathrm{~m} \text { with } \\
\text { muddy to sanddy-muddy bottoms }\end{array}$ & Subtropical & $0-120$ & 18.1 & Carnivorous & Pelagic \\
\hline L. crocea & Sciaenidae & $\begin{array}{l}\text { Marine; brackish; demersal; coastal waters and estuaries } \\
\text { with muddy to muddy-sandy bottoms shallower than } \\
\qquad 120 \mathrm{~m} \text { depth }\end{array}$ & Temperate & $0-120$ & 17 & Carnivorous & Pelagic \\
\hline S. aeolus & Sillaginidae & $\begin{array}{c}\text { Marine; demersal; nearshore shallow and estuarine } \\
\text { waters; burrowing life-style }\end{array}$ & Tropical & $0-60$ & 12 & Carnivorous & Pelagic \\
\hline S. japonica & Sillaginidae & $\begin{array}{l}\text { Marine; demersal; nearshore shallow and estuarine } \\
\text { waters; burrowing life-style }\end{array}$ & Subtropical & $0-30$ & - & Carnivorous & Pelagic \\
\hline S. parvisquamis & Sillaginidae & $\begin{array}{l}\text { Marine; brackish; demersal; nearshore shallow and } \\
\text { estuarine waters; burrowing life-style }\end{array}$ & Subtropical & $0-30$ & - & Carnivorous & Pelagic \\
\hline S. sihama & Sillaginidae & $\begin{array}{l}\text { Marine; brackish; reef-associated; nearshore shallow } \\
\text { and estuarine waters; burrowing life-style }\end{array}$ & Tropical & $0-60$ & 13-19.1 & Carnivorous & Pelagic \\
\hline S. sinica & Sillaginidae & $\begin{array}{l}\text { Marine; brackish; demersal; nearshore shallow and } \\
\text { estuarine waters; burrowing life-style }\end{array}$ & Tropical & - & - & Carnivorous & Pelagic \\
\hline S. sp.1 & Sillaginidae & - & - & - & - & - & - \\
\hline S. sp.2 & Sillaginidae & - & - & - & - & - & - \\
\hline
\end{tabular}




\subsection{Prediction of PSGs of Sillago Species}

In the present study, the codeml program in the PAML (Version 4.9, University College London, London, UK; [32]) software was applied to identify the PSGs of Sillago species. Firstly, we constructed tree files for 20 research species (including the seven Sillago species and 13 outgroups) using each single-copy orthologous gene, respectively. Subsequently, the branch-site model (model = 2, Nsites $=2$ ) in the codeml program was used to identify the PSGs of Sillago species, and a comparison was also conducted between the null and alternative models. The null model assumed that Sillago species were under purifying selection and that therefore those sites on the foreground branch evolved neutrally (non-synonymous $(\mathrm{dN}) /$ synonymous $(\mathrm{dS})=1$, modelA1, fix_omega $=1$, and omega $=1.5$ ), and the alternative model assumed that those sites on the foreground branch were under positive selection $(\mathrm{dN} / \mathrm{dS}>1$, modelA2, fix_omega $=0$, and omega $=1.5)$. Then, a likelihood ratio test $(\mathrm{LRT})$ was applied to calculate the log-likelihood values $(2 \triangle \ln )$ between the null model and alternative model of each single-copy orthologous gene. After a Chi-square statistical analysis, a gene was considered as a PSG of Sillago species if the FDR-adjusted $p<0.01$. Finally, we used the Blast2GO [33] software to predict the functions of those PSGs.

\section{Results}

\subsection{Illumina Sequencing and the De Novo Assembly of the Seven Sillago Species' Transcriptomes}

Illumina sequencing was carried out on muscle from the seven Sillago species. After cleaning and quality testing, we obtained $138.4 \mathrm{~Gb}$ of clean reads from the seven Sillago species, and the details of the data are listed in Table 2. All clean reads of the present study were uploaded to the SRA databases of NCBI under BioProject number PRJNA596307, with accession numbers of SRR10743279 to SRR10743285. The Trinity software was applied to the de novo assembly of the clean data, and 82,024, $58,102,102,185,69,748,102,903,63,807$, and 85,990 unigenes were generated from S. aeolus, S. japonica, S. parvisquamis, S. sihama, S. sinica, S. sp.1, and S. sp.2, respectively. The assembly information of the seven Sillago species is shown in Table 3. Additionally, the BUSCO analysis results showed that $91.5 \%$, $83.1 \%, 94.2 \%, 91.7 \%, 93.1 \%, 88.7 \%$, and $89.1 \%$ of protein-coding genes were found in the unigenes of S. aeolus, S. japonica, S. parvisquamis, S. sihama, S. sinica, S. sp.1, and S. sp.2, respectively.

Table 2. The clean transcriptomic reads of the seven Sillago species.

\begin{tabular}{cccc}
\hline Sillago Species & Read Number & $\mathbf{G C} \%$ & $\mathbf{\%} \geq \mathbf{Q 3 0}$ \\
\hline S. aeolus & $78,709,246$ & 51.14 & 92.37 \\
S. japonica & $50,013,641$ & 53.02 & 92.96 \\
S. parvisquamis & $113,351,008$ & 52.88 & 93.75 \\
S. sihama & $87,050,702$ & 51.34 & 92.63 \\
S. sinica & $97,977,199$ & 52.19 & 94.51 \\
S. sp.1 & $51,710,081$ & 53.86 & 93.74 \\
S. sp.2 & $70,996,526$ & 53.57 & 92.95 \\
\hline
\end{tabular}

Table 3. The transcriptome assembly information of the seven Sillago species.

\begin{tabular}{ccccc}
\hline \multirow{2}{*}{ Sillago Species } & \multicolumn{3}{c}{ Unigene } \\
\cline { 2 - 5 } & Number & Total Length (bp) & Mean Length (bp) & N50 Length (bp) \\
\hline S. aeolus & 82,024 & $51,896,226$ & 787.32 & 1,403 \\
S. japonica & 58,102 & $23,966,004$ & 428.99 & 461 \\
S. parvisquamis & 102,185 & $79,280,211$ & $1,019.38$ & 1,986 \\
S. sihama & 69,748 & $48,391,713$ & 815.81 & 1,369 \\
S. sinica & 102,903 & $78,264,349$ & 992.70 & 1,848 \\
S. sp.1 & 63,807 & $34,524,368$ & 588.49 & 738 \\
S. sp.2 & 85,990 & $49,751,159$ & 652.68 & 902 \\
\hline
\end{tabular}




\subsection{Orthologous Gene Identification and the Phylogenetic Structure of Sillago Species}

Single-copy conserved nuclear coding sequences of these eight model species were applied to search for orthologous genes in 20 research species. Using the HMMER software, we identified a set of 140 orthologous exon markers longer than 200bp. Then, the concatenated alignment of 140 orthologous genes produced a data matrix with $82,833 \mathrm{bp}$ for 20 research species. The $\mathrm{NJ}$ analyses of 20 concatenated nucleotide sequences, concatenated amino acid sequences, and concatenated variation sites were implemented in the MEGA package, and the phylogenetic structures of Sillago species are shown in Figures 2-4. According to all phylogenetic analyses, fishes from the same family eventually cluster into one branch, except for C. hamatus and G. acuticeps. Seven Sillago species, including two suspected new species, were also clearly distinguished from other Perciformes. Additionally, the divergence time was estimated, and the results showed that the internal divergence time varied within the seven Sillago species due to the different kind of concatenated sequence used for analysis. Specifically, the internal divergence times of the seven Sillago species based on concatenated nucleotide sequences was between 161.29 and 27.80 MYA, and the internal divergence time based on the amino acid sequences was between 27.02 and 4.15 MYA, while that based on variation sites was between 24.13 and 3.46 MYA.

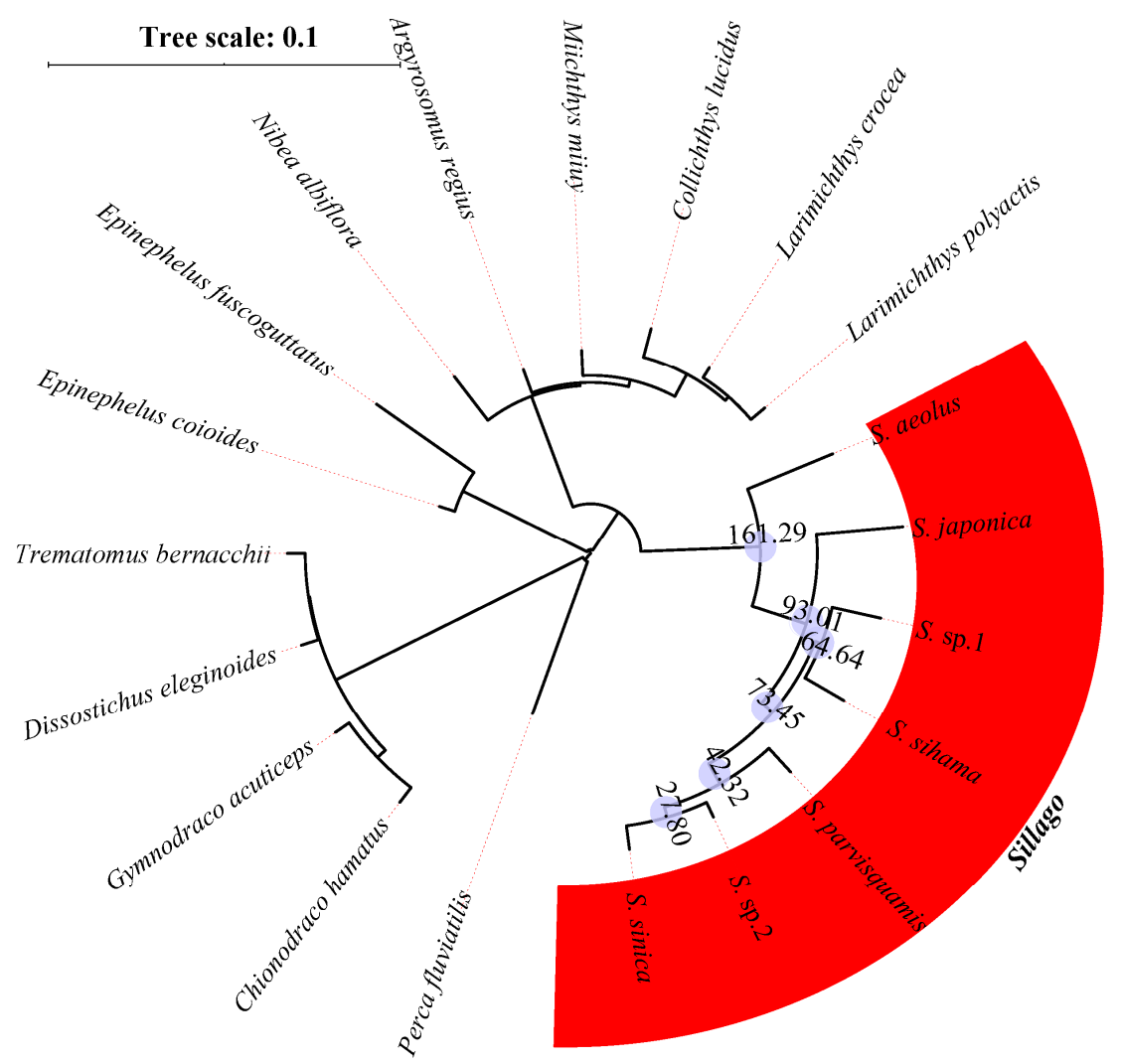

Figure 2. Inferred phylogenetic relationships and divergence times (data in the blue circles) of the seven Sillago species based on the concatenated nucleotide sequences. 


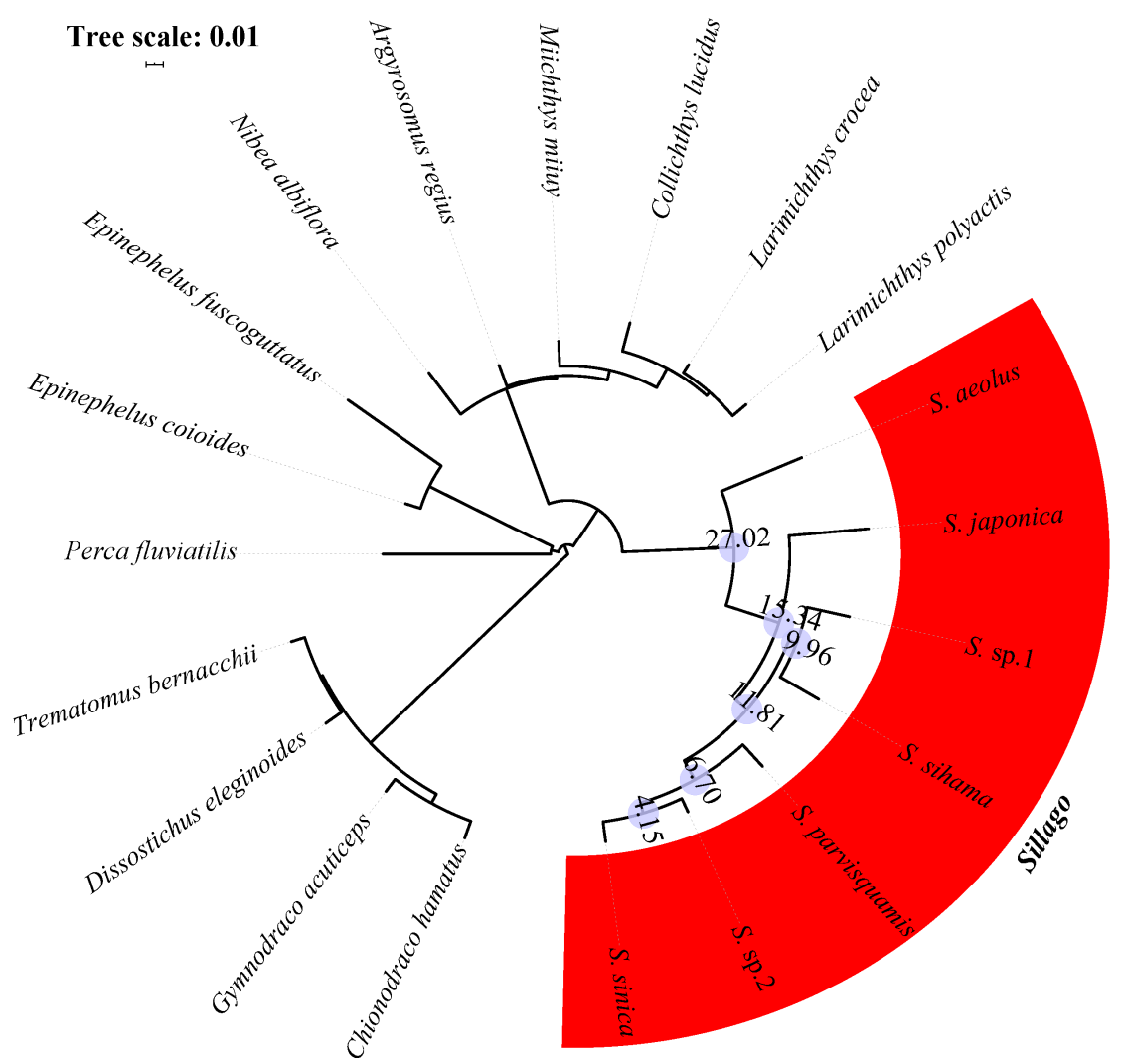

Figure 3. Inferred phylogenetic relationships and divergence times (data in the blue circles) of the seven Sillago species based on the concatenated amino acid sequences.

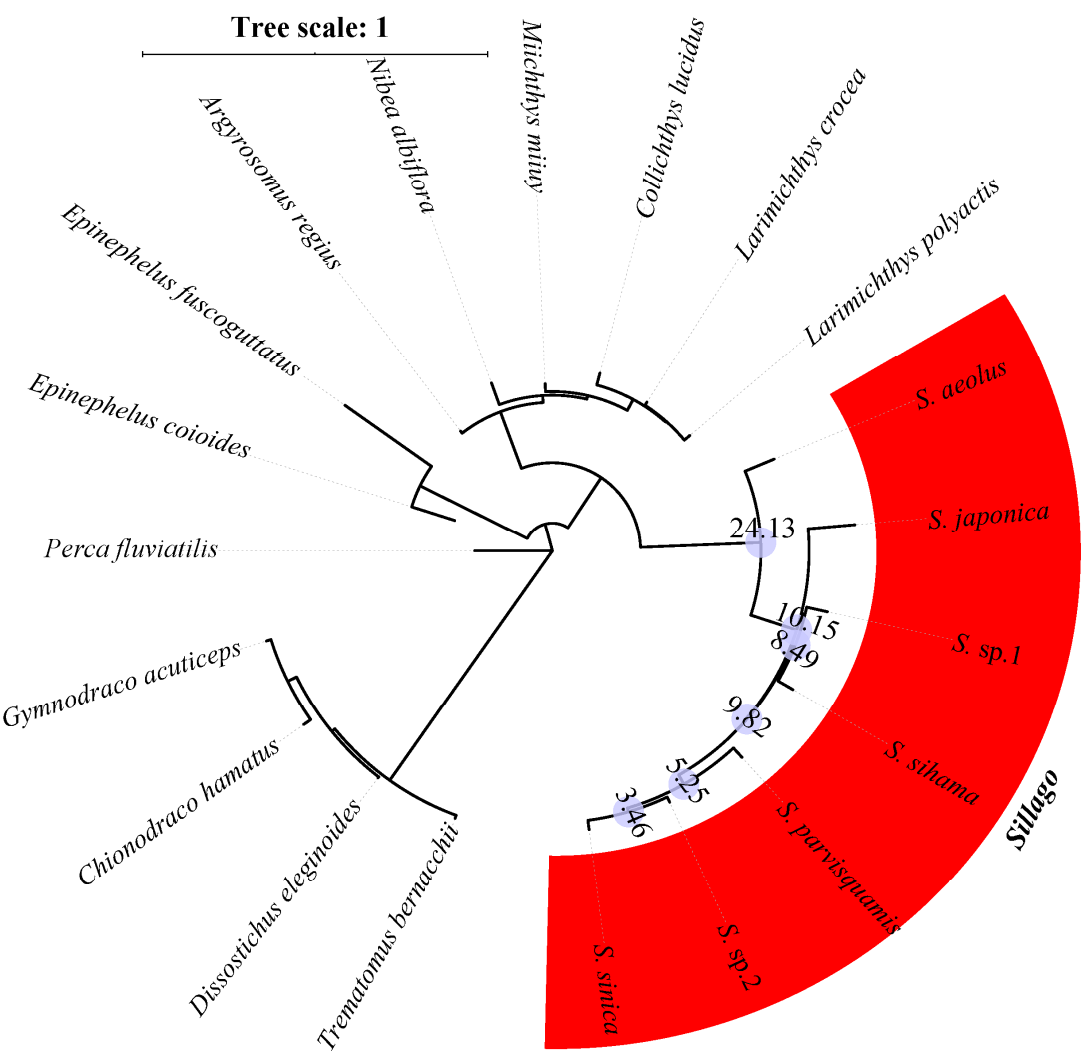

Figure 4. Inferred phylogenetic relationships and divergence times (data in the blue circles) of the seven Sillago species based on the concatenated variation sites. 


\subsection{PSGs Representative of Sillago Species}

We calculated the log-likelihood values $(2 \triangle \ln )$ between the null model and alternative model for 140 orthologous genes. After a Chi-square statistical analysis, a total of 44 genes with FDR-adjusted $p<0.05$ were identified as PSGs and these genes were suspected to contribute to the specific adaptive evolution of Sillago fishes in the burrowing lifestyle. (Table 4). Combining nr (non-redundant protein sequence) database annotation information, we speculate that these adaptive genes are potentially related to the stress response, material (amino acid and lipid) and energy metabolism, growth and differentiation, embryogenesis, visual sense, and other things. Further gene function enrichment analysis indicated that these adaptive genes were involved in cellular process (GO: 0050794), metabolic process (GO: 0006006), cell parts (GO: 0044464), cells (GO: 0005623), catalytic activity (GO: 0003824), binding (GO: 0005488), and other things (Figure 5). Additionally, we identified the networks of molecular interactions in the cells and variants specific to particular organisms by comparing the adaptive genes to the KEGG database (Table 5). Results showed that these adaptive genes were significantly enriched for nicotinate and nicotinamide metabolism (map00760), carbon fixation pathways in prokaryotes (map00720), purine metabolism (map00230), C5-Branched dibasic acid metabolism (map00660), starch and sucrose metabolism (map00500), arginine biosynthesis (map00220), riboflavin metabolism (map00740), pantothenate and CoA biosynthesis (map00770), pyrimidine metabolism (map00240), the biosynthesis of antibiotics (map01130), the citrate cycle (map00020), propanoate metabolism (map00640), thiamine metabolism (map00730), and arginine and proline metabolism (map00330).

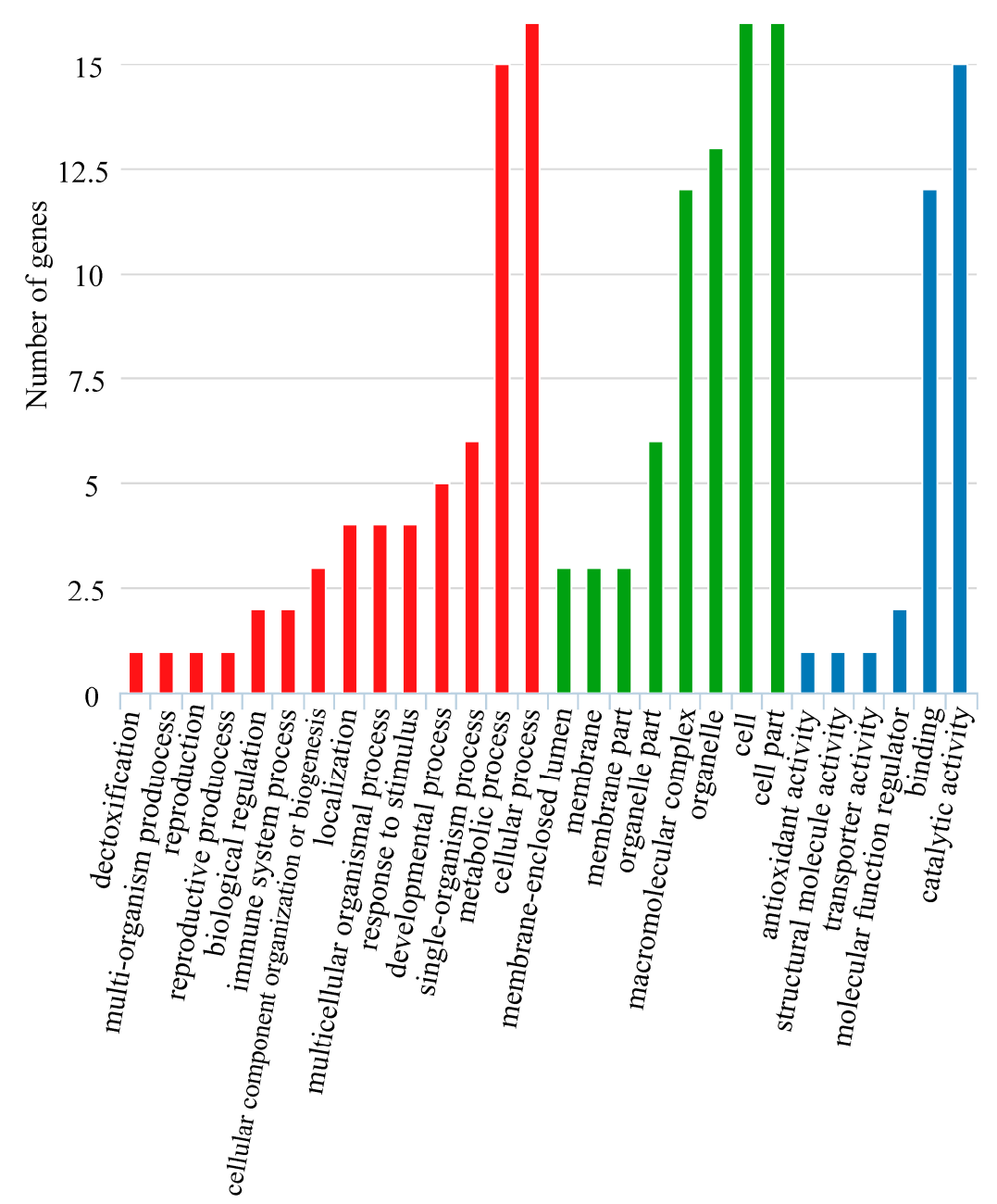

Figure 5. GO enrichment analysis of representative positively selected genes. 
Table 4. Representative positively selected genes in Sillago species.

\begin{tabular}{|c|c|c|c|c|}
\hline & Gene Name & Description & $\times 10$-Value & $\begin{array}{c}\text { FDR-Adjusted } \\
p \text {-Value }\end{array}$ \\
\hline \multirow{14}{*}{ Stress response } & MED27 & mediator of RNA polymerase II transcription subunit 27 & $3.02 \times 10^{-39}$ & 0.00 \\
\hline & MED28 & mediator of RNA polymerase II transcription subunit 28 & $2.33 \times 10^{-29}$ & 0.00 \\
\hline & LTV1 & protein LTV1 homolog & $1.08 \times 10^{-37}$ & $7.89 \times 10^{-03}$ \\
\hline & SMO & Spermine oxidase & $2.21 \times 10^{-22}$ & $1.27 \times 10^{-14}$ \\
\hline & PSA & puromycin-sensitive aminopeptidase & $3.70 \times 10^{-41}$ & 0.00 \\
\hline & $A B C B 7$ & ATP-binding cassette sub-family B member 7 , mitochondrial & $5.54 \times 10^{-31}$ & 0.00 \\
\hline & COPA & coatomer subunit alpha & $4.99 \times 10^{-45}$ & 0.00 \\
\hline & $S F 3 A 1$ & splicing factor $3 \mathrm{~A}$ subunit 1 & $2.31 \times 10^{-44}$ & 0.00 \\
\hline & SF3B5 & splicing factor $3 \mathrm{~B}$ subunit 5 & $8.30 \times 10^{-60}$ & 0.00 \\
\hline & $D E P D C 5$ & GATOR complex protein DEPDC5 isoform X3 & $1.72 \times 10^{-46}$ & 0.00 \\
\hline & $P O L \lambda$ & DNA polymerase lambda & $1.48 \times 10^{-80}$ & 0.00 \\
\hline & TFIP11 & tuftelin-interacting protein 11 & $2.10 \times 10^{-72}$ & 0.00 \\
\hline & NUDT6 & Nucleoside diphosphate-linked moiety $X$ motif 6 & $1.32 \times 10^{-83}$ & 0.00 \\
\hline & UBIAD1 & UbiA prenyltransferase domain-containing protein 1 & $7.59 \times 10^{-96}$ & 0.00 \\
\hline \multirow{2}{*}{ Energy metabolism } & $A P F$ & bis(5'-nucleosyl)-tetraphosphatase [asymmetrical] & $5.30 \times 10^{-64}$ & 0.00 \\
\hline & IMMT & MICOS complex subunit MIC60 isoform X2 & $1.66 \times 10^{-126}$ & $1.38 \times 10^{-04}$ \\
\hline $\begin{array}{l}\text { Carbohydrate } \\
\text { metabolism }\end{array}$ & SUCLG1 & succinate-CoA ligase [ADP/GDP-forming] subunit alpha, mitochondrial & $2.37 \times 10^{-23}$ & 0.00 \\
\hline \multirow{2}{*}{$\begin{array}{l}\text { Amino acid } \\
\text { metabolism }\end{array}$} & GCN1 & eIF-2-alpha kinase activator GCN1 & $1.82 \times 10^{-41}$ & 0.00 \\
\hline & $C P D$ & Carboxypeptidase D & $6.74 \times 10^{-46}$ & 0.00 \\
\hline \multirow{9}{*}{ Lipid metabolism } & HUWE1 & E3 ubiquitin-protein ligase HUWE1 isoform X1 & $3.95 \times 10^{-35}$ & $1.15 \times 10^{-03}$ \\
\hline & HUWE1 & E3 ubiquitin-protein ligase HUWE1 isoform X1 & $4.55 \times 10^{-24}$ & 0.00 \\
\hline & HUWE1 & E3 ubiquitin-protein ligase HUWE1 isoform X1 & $8.49 \times 10^{-54}$ & $7.85 \times 10^{-03}$ \\
\hline & HUWE1 & E3 ubiquitin-protein ligase HUWE1 isoform X1 & $1.31 \times 10^{-38}$ & 0.00 \\
\hline & HUWE1 & E3 ubiquitin-protein ligase HUWE1 isoform X1 & $1.48 \times 10^{-40}$ & 0.00 \\
\hline & HUWE1 & E3 ubiquitin-protein ligase HUWE1 isoform X1 & $1.40 \times 10^{-41}$ & 0.00 \\
\hline & FABZ & hydroxyacyl-thioester dehydratase type 2 , mitochondrial & $7.36 \times 10^{-80}$ & 0.00 \\
\hline & HUWE1 & E3 ubiquitin-protein ligase HUWE1 isoform X1 & $2.11 \times 10^{-117}$ & $5.07 \times 10^{-03}$ \\
\hline & HUWE1 & E3 ubiquitin-protein ligase HUWE1 isoform X1 & $1.57 \times 10^{-117}$ & 0.00 \\
\hline
\end{tabular}


Table 4. Cont

\begin{tabular}{|c|c|c|c|c|}
\hline & Gene Name & Description & $\times 10$-Value & $\begin{array}{c}\text { FDR-Adjusted } \\
p \text {-Value }\end{array}$ \\
\hline \multirow{2}{*}{ Visual sense } & $A P 4 B 1$ & AP-4 complex subunit beta- 1 & $5.00 \times 10^{-45}$ & 0.00 \\
\hline & PRF8 & Pre-mRNA-processing-splicing factor 8 & $2.12 \times 10^{-52}$ & 0.00 \\
\hline \multirow{4}{*}{$\begin{array}{l}\text { Growth and } \\
\text { differentiation }\end{array}$} & ABTB1 & ankyrin repeat and $\mathrm{BTB} / \mathrm{POZ}$ domain-containing protein 1 & $1.96 \times 10^{-36}$ & 0.00 \\
\hline & $U B E 4 A$ & ubiquitin conjugation factor $\mathrm{E} 4 \mathrm{~B}$ isoform $\mathrm{X} 2$ & $1.31 \times 10^{-29}$ & $1.11 \times 10^{-12}$ \\
\hline & GAB1 & GRB2-associated-binding protein 1 isoform $\mathrm{X} 1$ & $3.65 \times 10^{-61}$ & 0.00 \\
\hline & $\mathrm{DOHH}$ & deoxyhypusine hydroxylase & $2.66 \times 10^{-64}$ & 0.00 \\
\hline \multirow{3}{*}{ Embryogenesis } & SBDS & ribosome maturation protein SBDS & $2.55 \times 10^{-39}$ & 0.00 \\
\hline & SEC8 & exocyst complex component 8 & $1.38 \times 10^{-90}$ & 0.00 \\
\hline & TAF5L & $\begin{array}{c}\text { TAF5-like RNA polymerase II p300/CBP-associated factor-associated factor } 65 \mathrm{kDa} \\
\text { subunit 5L }\end{array}$ & 0.00 & 0.00 \\
\hline \multirow{7}{*}{ Others } & CCDC25 & Coiled-coil domain-containing protein 25 & $9.63 \times 10^{-17}$ & 0.00 \\
\hline & PIGY & phosphatidylinositol $\mathrm{N}$-acetylglucosaminyltransferase subunit $\mathrm{Y}$ & $1.12 \times 10^{-40}$ & 0.00 \\
\hline & - & fumarylacetoacetate hydrolase domain-containing protein 2-like isoform $\mathrm{X} 2$ & $6.37 \times 10^{-43}$ & 0.00 \\
\hline & USP24 & ubiquitin carboxyl-terminal hydrolase 24 isoform $\mathrm{X} 2$ & $5.15 \times 10^{-31}$ & 0.00 \\
\hline & RPN2 & $26 \mathrm{~S}$ proteasome non-ATPase regulatory subunit 1 & $2.38 \times 10^{-44}$ & 0.00 \\
\hline & CXORF56 & UPF0428 protein CXorf56 homolog & $1.53 \times 10^{-136}$ & 0.00 \\
\hline & TALIN & talin rod domain-containing protein 1 & 0.00 & $3.81 \times 10^{-06}$ \\
\hline
\end{tabular}


Table 5. KEGG pathway enrichment analysis of representative PSGs.

\begin{tabular}{|c|c|c|c|}
\hline Pathway & Pathway_ID & Key Enzyme & Gene Name \\
\hline $\begin{array}{c}\text { Nicotinate and } \\
\text { nicotinamide metabolism }\end{array}$ & map00760 & diphosphatase & $A P F$ \\
\hline $\begin{array}{l}\text { Carbon fixation } \\
\text { pathways in prokaryotes }\end{array}$ & map00720 & ligase (ADP-forming) & SUCLG1 \\
\hline Purine metabolism & map00230 & $\begin{array}{c}\text { adenylpyrophosphatase; } \\
\text { diphosphatase; } \\
\text { phosphatase }\end{array}$ & $A B C B 7, A P F, A B C B 7$ \\
\hline $\begin{array}{c}\text { C5-Branched dibasic acid } \\
\text { metabolism }\end{array}$ & map00660 & ligase (ADP-forming) & SUCLG1 \\
\hline $\begin{array}{c}\text { Starch and sucrose } \\
\text { metabolism }\end{array}$ & map00500 & diphosphatase & $A P F$ \\
\hline Arginine biosynthesis & map00220 & synthase (NADPH) & UBIAD1 \\
\hline Riboflavin metabolism & map00740 & diphosphatase & $A P F$ \\
\hline $\begin{array}{l}\text { Pantothenate and CoA } \\
\text { biosynthesis }\end{array}$ & map00770 & diphosphatase & $A P F$ \\
\hline Pyrimidine metabolism & map00240 & diphosphatase & $A P F$ \\
\hline $\begin{array}{l}\text { Biosynthesis of } \\
\text { antibiotics }\end{array}$ & map01130 & $\begin{array}{l}\text { synthase (NADPH); } \\
\text { ligase (ADP-forming); } \\
\text { ligase (GDP-forming) }\end{array}$ & $\begin{array}{l}\text { UBIAD1, SUCLG1, } \\
\text { SUCLG1 }\end{array}$ \\
\hline Citrate cycle (TCA cycle) & map00020 & $\begin{array}{l}\text { ligase (ADP-forming); } \\
\text { ligase (GDP-forming) }\end{array}$ & SUCLG1, SUCLG1 \\
\hline Propanoate metabolism & map00640 & $\begin{array}{l}\text { ligase (ADP-forming); } \\
\text { ligase (GDP-forming) }\end{array}$ & SUCLG1, SUCLG1 \\
\hline Thiamine metabolism & map00730 & Phosphatase & $A B C B 7$ \\
\hline $\begin{array}{l}\text { Arginine and proline } \\
\text { metabolism }\end{array}$ & map00330 & synthase (NADPH) & UBIAD1 \\
\hline
\end{tabular}

\section{Discussion}

As they are typical marine demersal fish, species differentiation of Sillago species is often disordered, which ultimately affects the accurate interpretation by taxonomists of their evolutionary processes. Meanwhile, more complex habitat environments caused by climate change and human activities can also have an impact on the survival of Sillago species. However, it is undeniable that unraveling their complete phylogenetic relationships and adaptive mechanisms can effectively solve the above problems. In order to gather this fundamental knowledge, we first sequenced and assembled the transcriptome of seven Sillago species. Then, we identified the orthologous genes of seven Sillago species and 13 other Perciformes species based on transcriptome data. Finally, the phylogenetic relationships were reconstructed and the PSGs of Sillago species were inferred based on orthologous genes. In brief, we believe that this research can provide new perspectives for protecting the Sillago fishery resource.

\subsection{Transcriptome Data Processing}

In the present study, we obtained $138.4 \mathrm{~Gb}$ of clean transcriptomic data from seven Sillago species. To our knowledge, this study may be the first systematic research of seven Sillago species' transcriptomes by using high-throughput sequencing technology, except for S. japonica [34]. It is undeniable that the transcriptome assembly results of $S$. japonica, S. sp.1, and S. sp.2 are imperfect because their N50 lengths are less than $1000 \mathrm{bp}$. Meanwhile, the BUSCO results also found that the unigenes of S. japonica, S. sp.1, and S. sp.2 lacked integrity. This is the case because some of the reads contaminated by the sequencing process were removed. Additionally, the selection of the reference genome (the S. sinica genome was selected as the reference sequence in this study) and assembly strategy (software and parameters) can also influence the final assembly efficiency. However, we still believe that these data expand the currently available genomic resources for Sillago species. 


\subsection{More Accurately Determining the Phylogenetic Relationships of Seven Sillago Species}

Knowledge of the phylogeny of Sillago species is insufficient due to their similar phenotypic and physiological characteristics. Additionally, the paucity of genomic resources has restricted the phylogenetic resolution of Sillago species relationships. Currently established high-throughput sequencing technologies enable systematists to acquire huge amounts of orthologous genes for phylogenetic relationship reconstruction for Sillago species [23]. It is well known that the differentiation of orthologous genes usually leads to the speciation of species [35]. Therefore, there is every reason to believe that we can more accurately determine the phylogenetic relationships of Sillago species based on hundreds to thousands of orthologous genes. Although more complete orthologous genes could be obtained based on whole-genome sequencing technology, their application in phylogenetic analysis is limited by the high sequencing cost and methodological challenges of big databases [13]. With this background, orthologous exon markers captured by transcriptome sequencing have been attempted to be used in phylogenetic studies [36]. In fact, Betancur-R et al. (2013) considered that exons can be translated to amino acids, and further, to reduce errors from base compositional biases in phylogenetic studies [37]. Therefore, we focused on orthologous exon markers to reconstruct the phylogenetic relationships between seven Sillago species in this study. Unfortunately, only 140 orthologous exon markers were obtained using the HMMER method, and we suspected it may be related to the imperfect assembly results for S. japonica, S. sp.1, and S. sp.2. Although the number of markers is small, their efficiency has been verified by Hughes et al. [23], thus we believed that these markers are suitable for subsequent phylogenetic relationship reconstruction. Unsurprisingly, the reconstructed phylogenetic structure based on 140 orthologous exon markers (nucleotide sequences, amino acid sequences, and variation sites) is significantly congruent with the prevailing morphological and molecular biological view of Perciformes species relationships, except for C. hamatus and G. acuticeps. In other words, fishes from the same family eventually cluster into one branch. The reconstructed phylogenetic relationships of seven Sillago species are consistent with the results based on the mitochondrial genome [38]. Our study also provided evidence to prove that $S$. sp.1 and $S$. sp.2 may belong to the cryptic species of Sillago. However, more detailed evidence, including ecological and morphological data, needs to be provided in the further definition of S. sp.1 and S. sp.2. Additionally, there is no denying the fact that we still need to supplement other Sillago transcriptome data to reconstruct a more comprehensive understanding of phylogenetic relationships. It is worth noting that C. hamatus and G. acuticeps belong to the family Channichthyidae and Bathydraconidae, respectively, but the two species were clustered into one branch in this study. We suspected that the accuracy of the data may have contributed to the divergence. Additionally, some markers that were used to construct phylogenetic relationships between C. hamatus and G. acuticeps may have genetic convergence [39], which eventually cause the two species to cluster into one branch. This also confirmed that the selection of genetic markers may influence the reconstruction results of phylogenetic relationships [40]. Further studies will need larger datasets to illustrate the divergence.

The evolutionary sequence of Sillago species was identified based on differentiation times. The evolutional sequence of the seven Sillago species was consistent with that in previous studies [38]. Previous studies suspected that incomplete or missing swim bladders may be an adaptive mechanism for Sillaginidae species to demersal life [2]. In addition, Xiao (2018) also deduced that the swim bladders of Sillaginidae ancestors were extremely simple, and then became more complex as they evolved [38]. It is worth noting that the swim bladder of $S$. aeolus is imperfect relative to that in the other six Sillago species. Therefore, the evolutionary sequence of seven Sillago species based on transcriptome data also seems to support the hypothesis about the evolution of swim bladders. However, when evaluating the differentiation time of Sillago species based on different sequence formats, the results are quite different. In fact, Schwarzhans considered that Sillaginidae species gradually evolved into different species at Miocene (23 MYA to 5.33 MYA) [41]. Additionally, Takahashi has found an otolith fossil of Sillago from Niigata Prefecture (Japan) that may have existed during the Pliocene (5.3 MYA to 2.58 MYA) [42]. In the present study, the differentiation times based on amino acid sequences and variation sites 
are consistent with those in previous studies, although there existed a significant bias when using nucleotide sequences. We suspect that the base compositional biases caused by high-throughput sequencing affects the subsequent differentiation time analysis. However, it is undeniable that the tolerance of amino acid sequences to degenerate bases can effectively reduce this deviation [37]. Future studies still need to verify whether amino acid sequences and variation sites are more suitable for estimating the evolutionary order of species. Surprisingly, we used branch length to predict the differentiation times with other Perciformes species that might be quite different from those in the time tree database. There are two probable reasons: (1) the divergence in differentiation time results may be influenced by the estimation strategies and the number of genes used; (2) the orthologous exon markers obtained from transcriptome data are mostly functional genes, and the convergent evolution of functional genes has an inevitable effect on the evaluation of the species differentiation time.

In brief, transcriptome data can provide hundreds to thousands of single-copy orthologous exon markers, and then be used to reconstruct a more complete view of Sillago species phylogenetic relationships. However, when using orthologous exon markers obtained from transcriptome data to reconstruct phylogenetic relationships, two recommendations are worth considering: (1) the amino acid sequences of orthologous exon markers can reduce errors caused by base compositional biases, so it is necessary for phylogenetic relationship reconstruction; (2) the accuracy of phylogenetic relationships may be positively correlated with the number of orthologous exon markers used, which is possibly because a large number of markers can eliminate the bias from a small number of convergent evolutionary genes.

\subsection{Positively selected genes Might Contribute to the Ecological Adaptation of Sillago Species}

Transcriptome-wide analysis of the rates of non-synonymous to synonymous orthologous nucleotide substitutions represents an effective approach to quantitatively measure the selection force $[17,43]$. To reveal the molecular mechanism underlying the ecological adaptation of Sillago species, we estimated the dN/dS to identify the PSGs of Sillago species. A total of 44 orthologous genes were identified to be positively selected and might be involved in many biological processes, including the stress response (LTV1 [44], SMO [45], PSA [46,47], ABCB7 [48], UBIAD1 [49], COPA [50], MED27 [51,52], MED28 [51,52], SF3A1 [53], SF3B5 [53], TFIP11 [54], NUDT6 [55], POLA [56], and DEPDC5 [57]), energy metabolism (APF [58] and IMMT [59]), carbohydrate metabolism (SUCLG1 [60]), amino acid metabolism (GCN4 [61] and CPD [62]), lipid metabolism (HUWE1 [63] and FABZ [64]), visual sense (AP4B1 [65] and PRPF8 [66]), growth and differentiation (ABTB1 [67], UBE4A [68], DOHH [69], and GAB1 [70]), embryogenesis (SBDS [71], TAF5L [72], and SEC8 [73]), and others.

We suspected that the complexity (i.e., localized oxygen depletion, sulfide accumulation, and high turbidity) of the habitat environment may make Sillago species subject to multiple environmental stressors. Multiple environmental stressors might contribute to DNA damage and immunosuppression in Sillago species [74,75]. Meanwhile, the burrowing behavior of Sillago species may cause mechanical injuries to skin, and thus pathogens may enter the organism from the wound. Therefore, we suspected that those PSGs related to the stress response reflect the plasticity of Sillago species' adaptation to multiple environmental stressors. A previous study has considered that the foraging probability and food-intake of Sillago species larvae may be limited by low light [76]. The inadequate intake can further affect all kinds of behaviors that necessitate high energy consumption, such as predation, reproduction, and others [77]. Therefore, it is a questionable whether the positive selection of material and metabolism-related genes related to material and energy metabolism could maintain the energy compensation of Sillago species. Interestingly, two vision genes were found to be positively selected in Sillago species. The positive selection of vision genes can enhance the visual acuity of Sillago species, which is useful for some behaviors (predation, reproduction, and others) in low light [78]. Meanwhile, the retina of Sillago species may have possessed a well-developed vascularization due to the positive selection of vision genes, possibly to overcome the hypoxic conditions [78]. A previous study has also considered that light can affect the foraging, growth, and reproductive behavior and the circadian 
rhythms of fishes [79]. It has been discussed above that multiple environmental stressors may affect the stress response, predation behavior, material and energy metabolism, and visual sensitivity of Sillago species, which may eventually limit the survival and development of Sillago species. Therefore, we suspected that Sillago species might positively select a battery of genes associated with growth, differentiation, and embryogenesis to maintain their effective population numbers under multiple environmental stressors.

All in all, these PSGs might contribute to the ecological adaptation of Sillago species to the multiple environmental stressors, and these PSGs are also crucial to the evolution of Sillago species. However, our current evidence only shows specific protein sequence mutation in Sillago species. Whether these PSGs lead to favorable mutations in the phenotype of fish is unknown. Meanwhile, future experiments are also needed to explore which ecological traits of fish might have evolved along with these PSGs.

\section{Conclusions}

This study is the first systematic report of the transcriptome resource of Sillago species, and these data enrich the genomic information for molecular studies of these species. Based on eight well-annotated model fish genomes, we obtained 140 orthologous exon markers shared in Sillago species and then reconstructed a more complete phylogenetic relationship. Through the rates of non-synonymous to synonymous orthologous nucleotide substitutions, we found positive selection traces in 44 genes, and these genes are potentially related to the stress response, material (carbohydrate, amino acid, and lipid) and energy metabolism, growth and differentiation, embryogenesis, visual sense, and other things. This suggests that multiple environmental stressors may have led to specific selection force towards key genes in Sillago species. However, further experiments are needed to determine the exact function of these PSGs in Sillago species. Taken together, our results reconstruct a more complete view of the phylogenetic relationships of Sillago species based on transcriptome resources. We also suspect that the capacity of Sillago species to thrive in multiple environmental stressors may be due to the positive selection of these adaptive genes. The present study only represents a first step in understanding the habitat adaptive mechanism of the fish family Sillaginidae at the molecular level; further studies are still needed to validate the results and hypotheses.

Author Contributions: Conceptualization, T.G.; methodology, F.L.; validation, F.L., N.S., Y.Z., D.J. and T.G.; formal analysis, F.L.; sampling, D.J.; writing—original draft preparation, F.L.; writing-review and editing, F.L., Y.Z., N.S., D.J. and T.G.; supervision, T.G.; project administration, T.G.; funding acquisition, T.G. All authors have read and agreed to the published version of the manuscript.

Funding: This work was supported by the National Natural Science Foundation of China (41976083).

Acknowledgments: Sillago parvisquamis were provided by Hirotaka Nomura from Marine Ecology Research Institute (Chiba, Japan).

Conflicts of Interest: The authors declare no conflict of interest. The funders had no role in the design of the study; in the collection, analyses, or interpretation of data; in the writing of the manuscript, or in the decision to publish the results.

\section{References}

1. Mckay, R.J. A revision of the fishes of the family Sillaginidae. Mem. Queensl. Mus. 1985, 22, 1-73.

2. Kaga, T. Phylogenetic systematics of the family Sillaginidae (Percomorpha: Order Perciformes). Zootaxa 2013, 3642, 1-105. [CrossRef]

3. Mallet, A.L.; Carver, C.E.; Landry, T. Impact of suspended and off-bottom Eastern oyster culture on the benthic environment in eastern Canada. Aquaculture 2006, 255, 362-373. [CrossRef]

4. Xiao, J.; Song, N.; Han, Z.; Gao, T. Description and DNA barcoding of a new Sillago species, Sillago shaoi (perciformes: Sillaginidae), in the Taiwan Strait. Zool. Stud. 2016, 55, 47. [CrossRef]

5. Xu, S.; Xiao, S.; Zhu, S.; Zeng, X.; Luo, J.; Gao, T.; Chen, N. A draft genome assembly of the Chinese sillago (Sillago sinica), the first reference genome for Sillaginidae fishes. GigaScience 2018, 7, 108. [CrossRef] 
6. Gao, T.; Ji, D.; Xiao, Y.; Xue, T.; Yanagimoto, T.; Setoguma, T. Description and DNA barcoding of a new Sillago species, Sillago sinica (Perciformes: Sillaginidae), from coastal waters of China. Zool. Stud. 2011, 50, 254-263.

7. Golani, D.; Fricke, R.; Tikochinski, Y. Sillago suezensis, a new whiting from the northern Red Sea, and status of Sillago erythraea Cuvier (Teleostei: Sillaginidae). J. Nat. Hist. 2014, 48, 413-428. [CrossRef]

8. Qiu, Y.; Lee, J.; Bernasconiquadroni, F.; Soltis, D.E.; Soltis, P.S.; Zanis, M.; Zimmer, E.A.; Chen, Z.; Savolainen, V.; Chase, M.W. The earliest angiosperms: Evidence from mitochondrial, plastid and nuclear genomes. Nature 1999, 402, 404-407. [CrossRef]

9. Delsuc, F.; Brinkmann, H.; Philippe, H. Phylogenomics and the reconstruction of the tree of life. Nat. Rev. Genet. 2005, 6, 361-375. [CrossRef]

10. Liang, D.; Shen, X.; Zhang, P. One thousand two hundred ninety nuclear genes from a genome-wide survey support Lungfishes as the sister group of Tetrapods. Mol. Biol. Evol. 2013, 30, 1803-1807. [CrossRef]

11. Faircloth, B.C.; McCormack, J.E.; Crawford, N.G.; Harvey, M.G.; Brumfield, R.T.; Glenn, T.C. Ultraconserved elements anchor thousands of genetic markers spanning multiple evolutionary timescales. Syst. Biol. 2012, 61,717-726. [CrossRef]

12. Lemmon, A.R.; Emme, S.A.; Lemmon, E.M. Anchored hybrid enrichment for massively high-throughput phylogenomics. Syst. Biol. 2012, 61,727-744. [CrossRef]

13. Simion, P.; Philippe, H.; Baurain, D.; Jager, M.; Richter, D.J.; Di Franco, A.; Roure, B.; Satoh, N.; Quéinnec, É.; Ereskovsky, A.; et al. A large and consistent phylogenomic dataset supports sponges as the sister group to all other animals. Curr. Biol. 2017, 27, 958-967. [CrossRef]

14. Vandepoele, K.; De Vos, W.; Taylor, J.S.; Meyer, A.; Van de Peer, Y. Major events in the genome evolution of vertebrates: Paranome age and size differ considerably between ray-finned fishes and land vertebrates. Proc. Natl. Acad. Sci. USA 2004, 101, 1638-1643. [CrossRef]

15. Macqueen, D.J.; Johnston, I.A. A well-constrained estimate for the timing of the salmonid whole genome duplication reveals major decoupling from species diversification. Proc. Biol. Sci. 2014, 281, 20132881. [CrossRef]

16. Kang, J.; Ma, X.; He, S. Evidence of high-altitude adaptation in the glyptosternoid fish, Creteuchiloglanis macropterus from the Nujiang River obtained through transcriptome analysis. BMC Evol. Biol. 2017, 17, 229. [CrossRef]

17. Yang, L.; Wang, Y.; Zhang, Z.; He, S. Comprehensive transcriptome analysis reveals accelerated genic evolution in a Tibet fish, Gymnodiptychus pachycheilus. Genome Biol. Evol. 2014, 7, 251-261. [CrossRef]

18. Bolger, A.M.; Lohse, M.; Usadel, B. Trimmomatic: A flexible trimmer for Illumina sequence data. Bioinformatics 2014, 30, 2114-2120. [CrossRef]

19. Li, H.; Durbin, R. Fast and accurate short read alignment with Burrows-Wheeler Transform. Bioinformatics 2009, 25, 1754-1760. [CrossRef]

20. Li, H.; Handsaker, B.; Wysoker, A.; Fennell, T.; Ruan, J.; Homer, N.; Marth, G.; Abecasis, G.; Durbin, R. The sequence alignment/map format and SAMtools. Bioinformatics 2009, 25, 2078-2079. [CrossRef]

21. Haas, B.J.; Papanicolaou, A.; Yassour, M.; Grabherr, M.; Blood, P.D.; Bowden, J.; Couger, M.B.; Eccles, D.; Li, B.; Lieber, M.; et al. De novo transcript sequence reconstruction from RNA-seq using the Trinity platform for reference generation and analysis. Nat. Protoc. 2013, 8, 1494-1512. [CrossRef] [PubMed]

22. Froese, R.; Pauly, D. FishBase. World Wide Web electronic publication. 2019. Available online: www.fishbase. org (accessed on 24 February 2020).

23. Hughes, L.C.; Ortía, G.; Huang, Y.; Sun, Y.; Baldwin, C.C.; Thompson, A.W.; Arcila, D.; Betancur-R, R.; Li, C.; Becker, L.; et al. Comprehensive phylogeny of ray-finned fishes (Actinopterygii) based on transcriptomic and genomic data. Proc. Natl. Acad. Sci. USA 2018, 115, 6249-6254. [CrossRef] [PubMed]

24. Wheeler, T.J.; Eddy, S.R. nhmmer: DNA homology search with profile HMMs. Bioinformatics 2013, 29, 2487-2489. [CrossRef]

25. Li, W.; Godzik, A. Cd-hit: A fast program for clustering and comparing large sets of protein or nucleotide sequences. Bioinformatics 2006, 22, 1658-1659. [CrossRef] [PubMed]

26. Katoh, K.; Standley, D.M. MAFFT multiple sequence alignment software version 7: Improvements in performance and usability. Mol. Biol. Evol. 2013, 30, 772-780. [CrossRef]

27. Castresana, J. Selection of conserved blocks from multiple alignments for their use in phylogenetic analysis. Mol. Biol. Evol. 2000, 17, 540-552. [CrossRef] 
28. Tamura, K.; Stecher, G.; Peterson, D.; Filipski, A.; Kumar, S. MEGA6: Molecular evolutionary genetics analysis version 6.0. Mol. Biol. Evol. 2013, 30, 2725-2729. [CrossRef]

29. Letunic, I.; Bork, P. Interactive Tree of Life (iTOL) v4: Recent updates and new developments. Nucleic Acids Res. 2019, 47, 256-259. [CrossRef]

30. Hedges, S.B.; Marin, J.; Suleski, M.; Paymer, M.; Kumar, S. Tree of life reveals clock-like speciation and diversification. Mol. Biol. Evol. 2015, 32, 835-845. [CrossRef]

31. Sanderson, M.J. r8s: Inferring absolute rates of molecular evolution and divergence times in the absence of a molecular clock. Bioinformatics 2003, 19, 301-302. [CrossRef]

32. Yang, Z. PAML 4: Phylogenetic analysis by maximum likelihood. Mol. Biol. Evol. 2007, 24, $1586-1591$. [CrossRef] [PubMed]

33. Conesa, A.; Götz, S.; García-Gómez, J.M.; Terol, J.; Talón, M.; Robles, M. Blast2GO: A universal tool for annotation, visualization and analysis in functional genomics research. Bioinformatics 2005, 21, 3674-3676. [CrossRef] [PubMed]

34. Wu, R.X.; Zhang, H.R.; Niu, S.F.; Zhai, Y.; Liu, X.F. Development of polymorphic microsatellites for Sillago sihama based on next-generation sequencing and transferability to Sillago japonica. Genet. Mol. Res. 2016, 15, gmr15049046. [CrossRef] [PubMed]

35. Fitch, W.M. Distinguishing homologous from analogous proteins. Syst. Zool. 1970, 19, 99-113. [CrossRef]

36. Near, T.J.; Eytan, R.I.; Dornburg, A.; Kuhn, K.L.; Moore, J.A.; Davis, M.P.; Wainwright, P.C.; Friedman, M.; Smith, W.L. Resolution of ray-finned fish phylogeny and timing of diversification. Proc. Natl. Acad. Sci. USA 2012, 109, 13698-13703. [CrossRef]

37. Betancur-R, R.; Li, C.; Munroe, T.A.; Ballesteros, J.A.; Ortí, G. Addressing gene tree discordance and non-stationarity to resolve a multi-locus phylogeny of the flatfishes (Teleostei: Pleuronectiformes). Syst. Biol. 2013, 62, 763-785. [CrossRef]

38. Xiao, J.G. The Taxonomy, Phylogeny and Biogeography of Sillaginidae Species in China; Ocean University of China: Qingdao, China, 2018; (Abstract in English).

39. Parker, J.; Tsagkogeorga, G.; Cotton, J.A.; Liu, Y.; Provero, P.; Stupka, E.; Rossiter, S.J. Genome-wide signatures of convergent evolution in echolocating mammals. Nature 2013, 502, 228-231. [CrossRef]

40. Edwards, S.V.; Cloutier, A.; Baker, A.J. Conserved nonexonic elements: A novel class of marker for phylogenomics. Syst. Biol. 2017, 66, 1028-1044. [CrossRef]

41. Schwarzhans, W.W. Fish Otoliths from the New Zealand Tertiary; New Zealand Geological Survey: Lower Hutt, New Zealand, 1984.

42. Takahashi, M. On two fish-otoliths of Arctoscopus and Sillago (Teleostei) from the Kaidate Formation (Pliocene), Niigata Prefecture. Earth Sci. 1980, 34, 346-349. [CrossRef]

43. Voolstra, C.R.; Sunagawa, S.; Matz, M.V.; Bayer, T.; Aranda, M.; Buschiazzo, E.; DeSalvo, M.K.; Lindquist, E.; Szmant, A.M.; Coffroth, M.A.; et al. Rapid evolution of coral proteins responsible for interaction with the environment. PLoS ONE 2011, 6, e20392. [CrossRef]

44. Loar, J.W.; Seiser, R.M.; Alexandra, E.; Sagerson, H.J.; Ilias, N.; Zobel-Thropp, P.; Craig, E.A.; Lycan, D.E. Genetic and biochemical interactions among Yar1, Ltv1 and RpS3 define novel links between environmental stress and ribosome biogenesis in Saccharomyces cerevisiae. Genetics 2004, 168, 1877-1889. [CrossRef] [PubMed]

45. Vujcic, S.; Diegelman, P.; Bacchi, C.J.; Kramer, D.L.; Porter, C.W. Identification and characterization of a novel flavin-containing spermine oxidase of mammalian cell origin. Biochem. J. 2002, 367, 665-675. [CrossRef] [PubMed]

46. Bhutani, N.; Venkatraman, P.; Goldberg, A.L. Puromycin-sensitive aminopeptidase is the major peptidase responsible for digesting polyglutamine sequences released by proteasomes during protein degradation. EMBO J. 2007, 26, 1385-1396. [CrossRef] [PubMed]

47. Menzies, F.M.; Hourez, R.; Imarisio, S.; Raspe, M.; Sadiq, O.; Chandraratna, D.; O’Kane, C.; Rock, K.L.; Reits, E.; Goldberg, A.L.; et al. Puromycin-sensitive aminopeptidase protects against aggregation-prone proteins via autophagy. Hum. Mol. Genet. 2010, 19, 4573-4586. [CrossRef] [PubMed]

48. Vasiliou, V.; Vasiliou, K.; Nebert, D.W. Human ATP-binding cassette (ABC) transporter family. Hum. Genom. 2008, 3, 281-290. [CrossRef] [PubMed]

49. Nakagawa, K.; Hirota, Y.; Sawada, N.; Yuge, N.; Watanabe, M.; Uchino, Y.; Okuda, N.; Shimomura, Y.; Suhara, Y.; Okano, T. Identification of UBIAD1 as a novel human menaquinone-4 biosynthetic enzyme. Nature 2010, 468, 117-121. [CrossRef] 
50. Watkin, L.B.; Jessen, B.; Wiszniewski, W.; Vece, T.J.; Jan, M.; Sha, Y.; Thamsen, M.; Santos-Cortez, R.L.; Lee, K.; Gambin, T.; et al. COPA mutations impair ER-Golgi transport and cause hereditary autoimmune-mediated lung disease and arthritis. Nat. Genet. 2015, 47, 654-660. [CrossRef]

51. Cho, J.G.; Lim, K.H.; Park, S.G. MED28 increases the colony-forming ability of breast cancer cells by stabilizing the ZNF224 protein upon DNA damage. Oncol. Lett. 2018, 15, 3147-3154. [CrossRef]

52. Harris, C.C. Structure and function of the p53 tumor suppressor gene: Clues for rational cancer therapeutic strategies. J. Natl. Cancer Inst. 1996, 88, 1442-1455. [CrossRef]

53. He, X.; Zhang, P. Serine/arginine-rich splicing factor 3 (SRSF3) regulates homologous recombination-mediated DNA repair. Mol. Cancer 2015, 14, 158. [CrossRef]

54. Tannukit, S.; Crabb, T.L.; Hertel, K.J.; Wen, X.; Jans, D.A.; Paine, M.L. Identification of a novel nuclear localization signal and speckletargeting sequence of tuftelin-interacting protein 11, a splicing factor involved in spliceosome disassembly. Biochem. Biophys. Res. Commun. 2009, 390, 1044-1050. [CrossRef] [PubMed]

55. Sukhthankar, M.; Choi, C.K.; English, A.; Kim, J.S.; Baek, S.J. A potential proliferative gene, NUDT6, is down-regulated by green tea catechins at the post-transcriptional level. J. Nutr. Biochem. 2010, 21, 98-106. [CrossRef] [PubMed]

56. García-Díaz, M.; Domínguez, O.; López-Fernández, L.A.; de Lera, L.T.; Saníger, M.L.; Ruiz, J.F.; Párraga, M.; García-Ortiz, M.J.; Kirchhoff, T.; del Mazo, J.; et al. DNA polymerase lambda (Pol lambda), a novel eukaryotic DNA polymerase with a potential role in meiosis. J. Mol. Biol. 2000, 301, 851-867. [CrossRef] [PubMed]

57. Wang, X.; Liao, Z.; Lin, D. Review on the research of DEP domain function. Med. Recapitulate 2011, 17, 1772-1774. [CrossRef]

58. McLennan, A.G. The Nudix hydrolase superfamily. Cell. Mol. Life Sci. 2006, 63, 123-143. [CrossRef] [PubMed]

59. Cao, S.; Liu, Y.; Wang, H.; Mao, X.; Chen, J.; Liu, J.; Xia, Z.; Zhang, L.; Liu, X.; Yu, T. Ischemic postconditioning influences electron transport chain protein turnover in Langendorff-perfused rat hearts. PeerJ 2016, 4, e1706. [CrossRef]

60. Quan, X.; Sato-Miyata, Y.; Tsuda, M.; Muramatsu, K.; Asano, T.; Takeo, S.; Aigaki, T. Deficiency of succinyl-CoA synthetase a subunit delays development, impairs locomotor activity and reduces survival under starvation in Drosophila. Biochem. Biophys. Res. Commun. 2017, 483, 566-571. [CrossRef]

61. Marton, M.J.; Crouch, D.; Hinnebusch, A.G. GCN1, a Translational activator of GCN4 in Saccharomyces cerevisiae, is required for phosphorylation of eukaryotic translation initiation factor 2 by protein kinase GCN2. Mol. Cell. Biol. 1993, 13, 3541-3556. [CrossRef]

62. Varlamov, O.; Wu, F.; Shields, D.; Fricker, L.D. Biosynthesis and packaging of carboxypeptidase D into nascent secretory vesicles in pituitary cell lines. J. Biol. Chem. 1999, 274, 14040-14045. [CrossRef]

63. Nakatsukasa, K.; Nishimura, T.; Byrne, S.D.; Okamoto, M.; Takahashi-Nakaguchi, A.; Chibana, H.; Okumura, F.; Kamura, T. The ubiquitin ligase SCF (Ucc1) acts as a metabolic switch for the glyoxylate cycle. Mol. Cell 2015, 59, 22-34. [CrossRef]

64. Jung, Y.; Kim, S.; Lee, S.; Ha, K.S.; Lee, J. Effect of heterologous expression of genes involved in the elongation cycle of fatty acid synthesis on fatty acid production in Saccharomyces cerevisiae. Biotechnol. Bioprocess Eng. 2015, 20, 1-9. [CrossRef]

65. Accogli, A.; Hamdan, F.F.; Poulin, C.; Nassif, C.; Rouleau, G.A.; Michaud, J.L.; Srour, M. A novel homozygous AP4B1 mutation in two brothers with AP-4 deficiency syndrome and ocular anomalies. Am. J. Med. Genet. 2018, 176, 985-991. [CrossRef]

66. Luo, H.R.; Moreau, G.A.; Levin, N.; Moore, M.J. The human Prp8 protein is a component of both U2- and U12-dependent spliceosomes. RNA 1999, 5, 893-908. [CrossRef] [PubMed]

67. Roy, A.; Pahan, K. Ankyrin repeat and BTB/POZ domain containing protein-2 inhibits the aggregation of alpha-synuclein, Implications for Parkinson's disease. FEBS Lett. 2013, 587, 3567-3574. [CrossRef] [PubMed]

68. Contino, G.; Amati, F.; Pucci, S.; Pontieri, E.; Pichiorri, F.; Novelli, A.; Botta, A.; Mango, R.; Nardone, A.M.; Sangiuolo, F.C.; et al. Expression analysis of the gene encoding for the U-box-type ubiquitin ligase UBE4A in human tissues. Gene 2004, 328, 69-74. [CrossRef] [PubMed]

69. Epis, M.R.; Giles, K.M.; Kalinowski, F.C.; Barker, A.; Cohen, R.J.; Leedman, P.J. Regulation of expression of deoxyhypusine hydroxylase (DOHH), the enzyme that catalyzes the activation of eIF5A, by miR-331-3p and miR-642-5p in prostate cancer cells. J. Biol. Chem. 2012, 42, 35251-35259. [CrossRef] 
70. Yamasaki, S.; Nishida, K.; Yoshida, Y.; Itoh, M.; Hibi, M.; Hirano, T. Gab1 is required for EGF receptor signaling and the transformation by activated ErbB2. Oncogene 2003, 22, 1546-1556. [CrossRef]

71. Zhang, S.; Shi, M.; Hui, C.C.; Rommens, J.M. Loss of the mouse ortholog of the shwachman-diamond syndrome gene (Sbds) results in early embryonic lethality. Mol. Cell. Biol. 2006, 26, 6656-6663. [CrossRef]

72. Walker, K.A.; Blackwell, T.K. A broad but restricted requirement for TAF-5 (Human TAFII100) for embryonic transcription in Caenorhabditis elegans. J. Biol. Chem. 2003, 278, 6181-6186. [CrossRef]

73. Cole, R.A.; Synek, L.; Zarsky, V.; Fowler, J.E. SEC8, a subunit of the putative arabidopsis exocyst complex, facilitates pollen germination and competitive pollen tube growth. Plant Physiol. 2005, 138, 2005-2018. [CrossRef]

74. Kantidze, O.L.; Velichko, A.K.; Luzhin, A.V.; Razin, S.V. Heat stress-induced DNA damage. Acta Nat. 2016, 8, 75-78. [CrossRef]

75. Morales, M.E.; Derbes, R.S.; Ade, C.M.; Ortego, J.C.; Stark, J.; Deininger, P.L.; Roy-Engel, A.M. Heavy metal exposure influences double strand break DNA repair outcomes. PLoS ONE 2016, 11, e0151367. [CrossRef] [PubMed]

76. Battaglene, S.C.; McBride, S.; Talbot, R.B. Swim bladder inflation in larvae of cultured sand whiting, Sillago ciliata Cuvier (Sillaginidae). Aquaculture 1994, 128, 177-192. [CrossRef]

77. Fu, S.J.; Cao, Z.D.; Xie, X.J. Feeding metabolism and locomotion metabolism in fishes. Chin. J. Zool. 2008, 43, 150-159.

78. Bozzano, A. Vision in the rufus snake eel, Ophichthus rufus: Adaptive mechanisms for a burrowing life-style. Mar. Biol. 2003, 143, 167-174. [CrossRef]

79. Puvanendran, V.; Brown, J.A. Foraging, growth and survival of Atlantic cod larvae reared in different light intensities and photoperiods. Aquaculture 2002, 214, 131-151. [CrossRef]

(C) 2020 by the authors. Licensee MDPI, Basel, Switzerland. This article is an open access article distributed under the terms and conditions of the Creative Commons Attribution (CC BY) license (http://creativecommons.org/licenses/by/4.0/). 